\title{
PERANCANGAN KINERJA SISTEM INFORMASI DENGAN METODE BALANCED SCORECARD DAN ANALYTICAL HIERARCHY PROCESS
}

\author{
Lestari Retnawati \\ Program Studi Teknik Informatika, Universitas Wijaya Kusuma Surabaya \\ J1. Dukuh Kupang XX No.53, Dukuh Kupang, Dukuh Pakis, Surabaya, Jawa Timur \\ Email: lestari.047@gmail.com
}

\begin{abstract}
XYZ University as one of private universities in Surabaya which is quite in demand, has the support of Information Systems and Information Technology in carrying out its academic operational activities. But the existence of the information system has not been fully integrated with the related work units, and there are some information systems that are not used as the information system should be within the Technical Implementation Unit of the Information and Communication Technology (UPT TIK). UPT TIK itself is still less than the maximum in carrying out its duties as a unit that takes care of various things related to academic operational activities. As well as the institution itself does not have a strategic planning of information systems and technology coherent between the vision and mission with operational programs. By looking at the above problems, the constraints of information system performance at XYZ University lies in the system and employees and the inability of the institution to formulate and describe comprehensive strategic planning and strategic planning formulation model. Therefore, the authors conduct research with the title "Performance Design of Information System Using Balanced Scorecard (BSC) and Analytical Hierarchy Process (AHP)". Balanced Scorecard is a measure and a management system that views the performance of a business unit from four perspectives: financial perspective, customer perspective, internal business process perspective, and learning and growth perspective. Weighted results for each perspective are: customer perspective (42.8\%), internal business process perspective (35.0\%), growth and learning perspective (14.4\%), and financial perspective (7.8\%). Based on the weighting, performance evaluation is done by comparing the performance measurement result against the performance target. Performance evaluation is done by using Traffic Light System.
\end{abstract}

Keywords: Analytical Hierarchy Process, Balanced Scorecard, Traffic Light System

\section{ABSTRAK}

Universitas XYZ sebagai salah satu perguruan tinggi swasta di Surabaya yang cukup banyak diminati, memiliki dukungan sistem informasi dan teknologi informasi dalam melaksanakan aktivitas operasional akademiknya. Namun, keberadaaan sistem informasi tersebut belum terintegrasi sepenuhnya dengan unit-unit kerja terkait, serta terdapat beberapa sistem informasi yang tidak digunakan sebagaimana mestinya. Sistem informasi tersebut berada dalam nauangan Unit Pelaksanaan Teknis Teknologi Informasi dan Komunikasi (UPT TIK). UPT TIK sendiri masih kurang maksimal dalam menjalankan tugasnya sebagai unit yang mengurusi berbagai hal yang berhubungan dengan aktivitas operasional akademik. Pihak institusi sendiri belum memiliki perencanaan strategis sistem informasi dan teknologi yang koheren antara visi dan misi dengan program operasionalnya. Dengan melihat permasalahan tersebut, yang menjadi kendala kinerja sistem informasi di Universitas XYZ terletak pada sistem dan karyawan serta ketidakmampuan pihak institusi dalam merumuskan dan menjabarkan perencanaan strategis yang komprehensif dan model formulasi perencanaan strategis. Maka dari itu, penulis melakukan penelitian dengan judul Perancangan Kinerja Sistem Informasi dengan Metode Balanced Scorecard (BSC) dan Analytical Hierarchy Process (AHP). Balanced Scorecard adalah ukuran dan sistem manajemen yang memandang kinerja suatu unit bisnis dari empat perspektif yaitu perspektif keuangan, perspektif pelanggan, perspektif proses bisnis internal, serta perspektif pembelajaran dan pertumbuhan. Hasil pembobotan untuk masing-masing perspektif adalah: perspektif pelanggan $(42,8 \%)$, perspektif proses bisnis internal $(35 \%)$, perspektif pertumbuhan dan pembelajaran $(14,4 \%)$, serta perspektif keuangan $(7,8 \%)$. Berdasarkan pembobotan tersebut, evaluasi kinerja dilakukan dengan membandingkan hasil pengukuran kinerja terhadap target kinerja. Evaluasi kinerja ini dilakukan dengan menggunakan Traffic Light System.

Kata Kunci: Analytical Hierarchy Process, Balanced Scorecard, Traffic Light System 


\section{PENDAHULUAN}

Universitas XYZ sebagai salah satu perguruan tinggi swasta di Surabaya yang cukup banyak diminati, memiliki dukungan sistem informasi dan teknologi informasi dalam melaksanakan aktivitas operasional akademiknya Namun, keberadaaan sistem informasi belum terintegrasi sepenuhnya dengan unit-unit kerja terkait, serta terdapat beberapa sistem informasi yang tidak digunakan sebagaimana mestinya. Sistem informasi ini berada dalam nauangan Unit Pelaksanaan Teknis Teknologi Informasi dan Komunikasi (UPT TIK). UPT TIK sendiri masih kurang maksimal dalam menjalankan tugasnya sebagai unit yang mengurusi berbagai hal yang berhubungan dengan aktivitas operasional akademik. Pihak institusi sendiri belum memiliki perencanaan strategis sistem informasi dan teknologi yang koheren antara visi dan misi dengan program operasionalnya. Dengan melihat permasalahan tersebut, yang menjadi kendala kinerja sistem informasi di Universitas XYZ terletak pada sistem dan karyawan serta ketidakmampuan pihak institusi dalam merumuskan dan menjabarkan perencanaan strategis yang komprehensif dan model formulasi perencanaan strategis. Maka dari itu, penulis melakukan penelitian dengan judul Perancangan Kinerja Sistem Informasi Dengan Metode Balanced Scorecard (BSC) dan Analytical Hierarchy Process (AHP). Balanced Scorecard adalah ukuran dan sistem manajemen yang memandang kinerja suatu unit bisnis dari empat perspektif yaitu perspektif keuangan, perspektif pelanggan, perspektif proses bisnis internal, serta perspektif pembelajaran dan pertumbuhan. Untuk mengetahui tingkat kepentingan dan peranan dilakukan pembobotan. Teknik pembobotan yang digunakan untuk mengetahui tingkat kepentingan dan peranan dari tiap tolok ukur dan perspektif adalah Analytical Hierarchy Process. Adapun rumusan masalah di penelitian ini yaitu bagaimana mengembangkan sistem pengukuran kinerja sistem informasi, mengukur performance sistem yang ada saat ini, dan merancang langkah-langkah perbaikan. Berdasarkan rumusan masalah maka tujuan penelitian adalah menentukan Key Performance Indicators (KPI) yang dapat digunakan dalam menentukan langkah-langkah strategis dan juga untuk mengukur kinerja unit secara menyeluruh serta merancang langkah-langkah perbaikan kinerja saat ini sesuai dengan visi dan misi Universitas XYZ.

\section{TINJAUAN PUSTAKA}

\section{Balanced Scorecrad}

Metode balanced scorecard memberikan kerangka komprehensif untuk menjabarkan visi ke dalam sasaran-sasaran strategi. Sasaran-sasaran strategi yang komprehensif dapat dirumuskan karena metode balanced scorecard menggunakan empat perspektif: keuangan, pelanggan, proses bisnis internal, serta pembelajaran dan pertumbuhan [1]. Ringkasan penjabaran dari keempat perspektif itu adalah sebagai berikut:

1. Financial perspective, memberikan sasaran keuangan yang perlu dicapai oleh organisasi dalam mewujudkan visinya.

2. Customer perspective, memberikan gambaran segmen pasar yang dituju dan pelanggan beserta tuntutan kebutuhan yang dilayani oleh organisasi dalam upaya untuk mencapai sasaran keuangan tertentu.

3. Internal and proses business perspective, memberikan gambaran proses yang harus dibangun untuk melayani pelanggan dan untuk mencapai sasaran keuangan tertentu.

4. Learning and growth perspective, merupakan pemacu untuk membangun kompetensi personel, prasarana sistem informasi, serta suasana lingkungan kerja yang diperlukan untuk mewujudkan sasaran keuangan, pelanggan, dan proses bisnis internal.

Dalam metode balanced scorecard, perspektif finansial dan nonfinansial merupakan bagian dari sistem informasi yang integral sehingga dapat memberikan pedoman bagi para manajer dalam mengukur, mengevaluasi, dan menerjemahkan strategi organiasi di masa depan untuk mencapai tujuan bersama. Cara pengukuran dalam balanced scorecard adalah mengukur secara seimbang antara perspektif yang satu dengan perspektif yang lainnya dengan tolok ukur masing-masing 
perspektif. Kriteria keseimbangan digunakan untuk mengukur sampai sejauh mana sasaran strategis dicapai secara seimbang di semua perspektif [2].

\section{Analytical Hierarchy Process (AHP)}

AHP merupakan metode pengambilan keputusan yang melibatkan sejumlah kriteria dan alternatif yang dipilih berdasarkan pertimbangan semua kriteria terkait dalam bentuk hierarki [3]. AHP adalah suatu metode analisis dan sintesis yang dapat membantu proses pengambilan keputusan. AHP merupakan alat pengambil keputusan yang powerfull dan fleksibel yang dapat membantu dalam menetapkan prioritas-prioritas dan membuat keputusan dimana aspek-aspek kualitatif dan kuantitatif terlibat dan keduanya harus dipertimbangkan [4]. berikut.

Tahapan-tahapan pengambilan keputusan dalam metode AHP pada dasarnya adalah sebagai

1. Mendefinisikan masalah dan menentukan solusi yang diinginkan.

2. Membuat struktur hierarki yang diawali dengan tujuan umum, dilanjutkan dengan kriteriakriteria yang ingin diperingkat. Adapun bentuk struktur hierarki untuk penelitian ini yaitu:

a. Tingkat pertama: tujuan keputusan (goal). Dalam penelitian ini yang menjadi tujuan atau goal yaitu kinerja sistem informasi.

b. Tingkat kedua: kriteria-kriteria. Adapun kriterianya meliputi: perspektif pelanggan, perspektif proses bisnis internal, perspektif pembelajaran dan pertumbuhan, serta perspektif keuangan.

3. Membentuk matriks perbandingan berpasangan yang menggambarkan kontribusi relatif atau pengaruh setiap elemen terhadap masing-masing tujuan atau kriteria yang setingkat. Perbandingan dilakukakan berdasarkan pilihan atau judgement dari pembuat keputusan dengan menilai tingkat-tingkat kepentingan suatu elemen dibandingkan elemen lainnya.

4. Menormalkan data yaitu dengan membagi nilai dari setiap elemen di dalam matriks yang berpasangan dengan nilai total dari setiap kolom.

5. Menghitung nilai eigen vector dan menguji konsistensinya, jika tidak konsisten maka pengambilan data (preferensi) perlu diulangi. Nilai eigen vector yang dimaksud adalah nilai eigen vector maksimum yang diperoleh dengan menggunakan Matlab maupun secara manual.

6. Mengulangi langkah 3, 4, dan 5 untuk seluruh tingkat hierarki.

7. Menghitung eigen vector dari setiap matriks perbandingan berpasangan. Nilai eigen vector merupakan bobot setiap elemen. Langkah ini untuk mensintetis pilihan dalam penentuan prioritas elemen pada tingkat hierarki terendah sampai pencapaian tujuan.

8. Menguji konsistensi hierarki. Jika tidak memenuhi aturan $\mathrm{CR}<0,100$ maka penilaian harus diulangi kembali.

\section{Penelitian Terdahulu}

Dalam melakukan penelitian ini, dilakukan pembandingan terhadap beberapa penelitian yang telah dilakukan sebelumnya sebagai bahan pertimbangan serta pendukung dalam melaksanakan penelitian. Beberapa penelitian terdahulu dapat dilihat dari materi yang dibahas, lokasi tempat penelitian, maupun metode yang digunakan peneliti lain sebagai berikut:

1. Artikel yang ditulis oleh [5]. Tujuan dari penelitian ini yaitu mengevaluasi kinerja perusahaan dengan menerapkan empat perspektif dalam balanced scorecard (keuangan, pelanggan, proses bisnis internal, serta pertumbuhan dan learning) dan analisis SWOT. Persamaan dengan penelitian ini adalah sama-sama menggunakan balanced scorecard dan AHP. Perbedaan dengan penelitian ini terletak pada objek yang diteliti dan metode yang digunakan.

2. Artikel yang ditulis oleh [6]. Tujuan dari penelitian ini yaitu mengevaluasi kinerja perusahaan dengan menerapkan empat perspektif dalam balanced scorecard (keuangan, pelanggan, proses bisnis internal, serta pertumbuhan dan learning) dan Analitycal Network Process. Persamaan dengan penelitian ini adalah sama-sama menggunakan balanced scorecard. Perbedaan dengan penelitian ini terletak pada objek yang diteliti dan metode yang digunakan. 
3. Artikel yang ditulis oleh [7]. Tujuan dari penelitian ini mengevaluasi kinerja perusahaan dengan menerapkan empat perspektif dalam balanced scorecard (keuangan, pelanggan, proses bisnis internal, serta pertumbuhan dan learning) dan metode OMAX. Persamaan dengan penelitian ini adalah sama-sama menggunakan balanced scorecard. Perbedaan dengan penelitian ini terletak pada objek yang diteliti dan metode yang digunakan.

\section{METODE}

Dalam melaksanakan penelitian ini, dilakukan proses pengerjaan secara bertahap yang diuraikan sebagai berikut.

\section{Observasi Awal}

Langkah pertama yang harus dilakukan dalam penelitian ini adalah melakukan observasi pada objek penelitian dengan jalan:

1. Melakukan pengamatan terhadap objek penelitian kemudian mencari permasalahan apa yang timbul bagi manajemen. Pengamatan tersebut terdiri atas dua macam pengamatan yaitu:

a. Pengamatan langsung: Penulis terjun langsung ke lapangan untuk melakukan pengamatanpengamatan terhadap objek penelitian dan mencari informasi awal tentang objek penelitian yang kiranya dapat diangkat sebagai suatu permasalahan.

b. Pengamatan tidak langsung: Penulis mengadakan wawancara dengan pihak-pihak yang terkait pada objek penelitian untuk memperoleh informasi tentang permasalahan yang tengah dihadapi oleh objek penelitian.

2. Menentukan tingkat kepentingan permasalahan tersebut bagi manajemen jika diangkat menjadi suatu penelitian.

3. Untuk menentukan tingkat kepentingan permasalahan yang akan diangkat tersebut, penulis meminta pertimbangan dari pihak-pihak yang berkepentingan dalam objek penelitian dan juga berdasarkan pengamatan awal yang dilakukan terhadap objek penelitian.

\section{Perumusan Masalah dan Tujuan Penelitian}

Pada tahap ini, perlu dilakukan pengkajian masalah apa yang dihadapi Universitas XYZ dalam menganalisis kinerja pada sistem informasi serta solusi apa yang tepat dan layak digunakan. Dari perumusan masalah maka dapat menetapkan tujuan dari penelitian ini.

\section{Studi Pustaka dan Studi Lapangan}

1. Studi pustaka, didasarkan pada hasil perumusan masalah dan tujuan penelitian, yaitu melakukan kajian teori yang berhubungan dengan permasalahan yang diangkat. Adapun teoriteori yang digunakan dalam penelitian ini antara lain: manajemen strategis, Balanced Scorecard (BSC), Key Performed Indicator (KPI), Analytical Hierarchy Process (AHP), sistem scoring, dan Traffic Light System.

2. Studi lapangan, mengambil data yang berkaitan dengan penelitian, yaitu: profil Universitas XYZ serta wawancara dan kuesioner.

\section{Perancangan dan Analisis Kinerja Sistem Informasi}

Dari hasil studi pustaka dan pengumpulan data, dapat dianalisis sistem pengukuran kinerja dengan metode balanced scorecard dengan tahapan sebagai berikut.

1. Mengidentifikasi sasaran strategi berdasarkan balanced scorecard: Menghubungkan sasaran strategis manajemen dengan pengukuran balanced scorecard dengan menentukan kunci kinerja masing-masing variabel untuk setiap perspektif dalam balanced scorecard.

2. Melakukan pembobotan KPI dengan AHP.

a. Melakukan pembobotan sasaran strategis organisasi/KPI dengan metode AHP. Model AHP ini mempunyai kelebihan karena dapat digunakan untuk memecahkan masalah pengambilan 
keputusan dengan banyak objektif dan kriteria. Selain itu, AHP adalah model pengambilan keputusan dengan input data kuantitatif dan kualitatif sekaligus.

b. Mendefinisikan masing-masing sasaran strategis meliputi tolok ukur sampai dengan target yang ditetapkan serta strategi pencapaiannya

\section{Melakukan Scoring dan Traffic Light System}

1. Melakukan Scoring

a. Menyamakan dimensi dari masing-masing satuan sasaran strategis sehingga diperoleh nilai akhir dari pengukuran kinerja.

b. Membuat standar penilaian masing-masing sasaran strategis berdasarkan target dan pencapaian serta pembatasannya dengan menggunakan sistem scoring.

c. Metode scoring digunakan untuk membuat pilihan atas dasar variabel-variabel penilaian dengan skala pengukuran yang berbeda-beda maka dibuat suatu standar penilaian dari masing-masing variabel tersebut ke dalam penilaian yang telah disepakati.

2. Melakukan Traffic Light System, digunakan sebagai tanda apakah score pada Key Performance Indikator (KPI) perlu diperbaiki atau tidak.

\section{Penerapan dan Perbaikan Kinerja Sistem Informasi}

Dari hasil analisis kinerja yang diperoleh akan dilakukan penerapan dengan membuat penilaian dari setiap tolok ukur masing-masing perspektif dengan menggunakan sistem scoring dan dilakukan perbaikan kinerja sehingga diperoleh ukuran kinerja yang dapat memberikan informasi terhadap penerapan hasil analisis sistem pengukuran kinerja.

\section{Kesimpulan dan Saran}

Setelah dilakukan implementasi dan hasil yang diperoleh telah sesuai dengan tujuan yang ditetapkan maka akan diambil kesimpulan mengenai semua tahapan yang telah dilalui serta diberikan saran sebagai masukan memperbaiki kekurangan-kekurangan pada penelitian yang telah dilakukan.

\section{HASIL DAN PEMBAHASAN}

\section{Hasil Pengolahan Data dengan Metode Balanced Scorecard}

Hasil pengolahan data dengan metode balanced scorecard dari survei dan wawancara di Universitas XYZ disajikan pada Tabel 1.

Tabel 1. Penjabaran Key Performance Indicator (KPI) Universitas XYZ

\begin{tabular}{llll}
\hline Perspektif & Sasaran Strategis & Key Performance Indicator (KPI) & Simbol \\
\hline Perspektif Pelanggan & $\begin{array}{l}\text { Peningkatan Kualitas } \\
\text { Layanan }\end{array}$ & $\begin{array}{l}\text { Peningkatan Akses Internet } \\
\text { Peningkatan Jumlah Database }\end{array}$ & P.PL1.1 \\
\cline { 2 - 4 } & $\begin{array}{l}\text { Perluasan Jaringan dan } \\
\text { Pemeliharaan Jaringan }\end{array}$ & $\begin{array}{l}\text { Peningkatan Kuantitas Jaringan } \\
\text { Jumlah Jaringan Berkondisi Baik }\end{array}$ & P.PL2.1 \\
& & & \\
\hline $\begin{array}{l}\text { Perspektif Proses } \\
\text { Bisnis Internal }\end{array}$ & Peningkatan Inovasi & $\begin{array}{l}\text { Penerapan Sistem Nilai Online via } \\
\text { SMS }\end{array}$ & P.PB1.1 \\
& & $\begin{array}{l}\text { Peningkatan Jumlah Aplikasi } \\
\text { Berbasis Web }\end{array}$ & P.PB1.2 \\
& & $\begin{array}{l}\text { Persentase Jumlah Pekerjaan } \\
\text { Yang Sudah Terkomputerisasi }\end{array}$ & P.PB2.1 \\
\cline { 2 - 4 } & $\begin{array}{l}\text { Peningkatan } \\
\text { Produktivitas }\end{array}$ & Peningkatan Efisiensi \\
& Pendidikan & Maintenance Sistem Informasi & \\
& & & \\
& & & \\
\hline
\end{tabular}




\begin{tabular}{llll}
\hline Perspektif & Sasaran Strategis & Key Performance Indicator (KPI) & Simbol \\
\hline $\begin{array}{l}\text { Perspektif } \\
\text { Pembelajaran dan } \\
\text { Pertumbuhan }\end{array}$ & Peningkatan Kualitas & Peningkatan Jumlah Karyawan & P.PP1.1 \\
& Sumber Daya Manusia & $\begin{array}{l}\text { Yang Paham Sistem Informasi } \\
\text { Peningkatan Jumlah Karyawan }\end{array}$ & P.PP1.2 \\
\hline Perspektif Keuangan & $\begin{array}{l}\text { Optima Dilatih Sistem Informasi } \\
\text { Pendapatan }\end{array}$ & $\begin{array}{l}\text { Persentase Anggaran Sistem } \\
\text { Informasi } \\
\text { Persentase Layanan Keuangan }\end{array}$ & P.KEU1.1 \\
& & P.KEU1.2 \\
\hline
\end{tabular}

Sumber: Hasil Survei dan Wawancara di Universitas XYZ

\section{Pengolahan Data dengan Analytical Hierarchy Process (AHP)}

Pengolahan data dimulai dengan melihat data hasil kuesioner kemudian dilakukan perhitungan dengan menggunakan metode AHP. Hasil pembobotan menggunakan AHP dapat dilihat pada Tabel 2.

Tabel 2 Hasil Pembobotan Key Performance Indicators (KPI)

\begin{tabular}{lrr}
\hline Key Performance Indicators (KPI) & Bobot & Bobot Total \\
\hline Perspektif Pelanggan & 0,428 \\
- Peningkatan Akses Internet & 0,241 & \\
- Peningkatan Jumlah Database & 0,080 & \\
- Peningkatan Kuantitas Jaringan & 0,081 & \\
- Jumlah Jaringan Berkondisi Baik & 0,026 & \\
Perspektif Proses Bisnis Internal & 0,197 & \\
- Penerapan Sistem Nilai Online via SMS & 0,065 & \\
- Peningkatan Jumlah Aplikasi Berbasis Web & 0,066 & \\
- Persentase Jumlah Pekerjaan Yang Sudah Terkomputerisasi & 0,022 & \\
- Peningkatan Efisiensi Maintenance Sistem Informasi & 0,144 \\
Perspektif Pembelajaran dan Pertumbuhan & 0,108 & \\
- Peningkatan Jumlah Karyawan yang Paham Sistem Informasi & \\
- Peningkatan Jumlah Karyawan yang Dilatih Sistem Informasi & 0,036 & 0,078 \\
Perspektif Keuangan & 0,058 & \\
- Persentase Anggaran Sistem Informasi & 0,020 & \\
- Persentase Layanan Keuangan & & 1,000 \\
\hline \multicolumn{2}{c}{ TOTAL } \\
\hline
\end{tabular}

\section{Hasil Perhitungan Dengan Scoring Dan Traffic Light System}

Berdasarkan hasil perhitungan dengan scoring dan Traffic Light System, maka diperoleh hasil penilaian kinerja terhadap masing-masing KPI sebagai berikut.

1. Indikator kinerja hijau, yaitu indikator kinerja yang berada pada level 8-10, tergolong pada penilaian performansi baik, yang realisasinya hampir mendekati atau bahkan dapat mencapai target yang telah ditetapkan, meliputi:

a. PL1.1: Peningkatan Akses Internet

b. PB1.1: Penerapan Sistem Nilai Online via SMS

c. PB2.1: Persentase Jumlah Pekerjaan yang Sudah Terkomputerisasi

d. PB2.2: Peningkatan Efisiensi Maintenance Sistem Informasi

2. Indikator kinerja kuning, yaitu indikator kinerja yang berada pada level 4-7, tergolong pada penilaian performa cukup, yang realisasinya belum mencapai target meskipun nilainya sudah mendekati target yang telah ditetapkan, meliputi:
a. PL1.2: Peningkatan Jumlah Database
b. PL2.2: Jumlah Jaringan Berkondisi Baik
c. PP1.1: Peningkatan Jumlah Karyawan yang Paham Sistem Informasi 
3. Indikator kinerja merah, yaitu indikator kinerja yang berada pada level 0-3, tergolong pada penilaian performansi jelek, yang realisasinya berada di bawah target yang telah ditetapkan, meliputi:
a. PL2.1 : Peningkatan Kuantitas Jaringan
b. PB1.2 : Peningkatan Jumlah Aplikasi Berbasis Web
c. PP1.2 : Peningkatan Jumlah Karyawan yang Dilatih Sistem Informasi
d. PKEU1.1 : Persentase Anggaran Sistem Informasi
e. PKEU1.2 : Persentase Layanan Keuangan

\section{Analisis Perbaikan}

Analisis perbaikan dilakukan pada key performance indicator yang masuk kategori berwarna merah karena dapat menyebabkan penurunan kinerja sistem informasi di Universitas XYZ. Hasil dari analisis perbaikan dengan menggunakan Root Cause Analysis (RCA) dapat dilihat pada Tabel 3.

Tabel 3 Perbaikan Pada Key Performance Indicator

\begin{tabular}{|c|c|c|}
\hline No. & Key Performance Indicator & Perbaikan \\
\hline 1. & Peningkatan Kuantitas Jaringan & $\begin{array}{l}\text { Perluasan jaringan dan Melakukan pengembangan } \\
\text { jaringan }\end{array}$ \\
\hline 2. & $\begin{array}{l}\text { Peningkatan Jumlah Aplikasi } \\
\text { Berbasis Web }\end{array}$ & $\begin{array}{l}\text { Pembuatan aplikasi berbasis web dan Pembangunan } \\
\text { aplikasi berbasis web menggunakan software open } \\
\text { source }\end{array}$ \\
\hline 3. & $\begin{array}{l}\text { Peningkatan Jumlah Karyawan } \\
\text { yang Dilatih Sistem Informasi }\end{array}$ & $\begin{array}{l}\text { Memberikan pelatihan khusus tentang sistem informasi } \\
\text { dan Memberikan motivasi tentang pentingnya sistem } \\
\text { informasi bagi karyawan }\end{array}$ \\
\hline 4. & $\begin{array}{l}\text { Persentase Anggaran Sistem } \\
\text { Informasi }\end{array}$ & $\begin{array}{l}\text { Pengelolaan keuangan harus dilakukan secara } \\
\text { transparan dan Mencari tenaga ahli di bidang } \\
\text { manajemen keuangan untuk merapikan dan mengontrol } \\
\text { tentang keuangan di Universitas XYZ }\end{array}$ \\
\hline 5. & Persentase Layanan Keuangan & $\begin{array}{l}\text { Melakukan Optimalisasi Pendapatan untuk } \\
\text { Peningkatan Pendidikan dan Pengelolaan keuangan } \\
\text { harus dilakukan secara transparan }\end{array}$ \\
\hline
\end{tabular}

\section{KESIMPULAN}

Dari hasil pengukuran kinerja dengan metode balanced scorecard yang telah dilakukan, dapat diambil kesimpulan sebagai berikut.

1. Berdasarkan penyusunan sistem pengukuran kinerja dengan menggunakan metode balanced scorecard yang telah dilakukan, maka dalam empat perspektif didapatkan enam sasaran strategi Universitas XYZ, antara lain: peningkatan kualitas layanan, perluasan jaringan dan pemeliharaan jaringan, peningkatan inovasi, peningkatan produktivitas pendidikan, peningkatan kualitas sumber daya manusia, serta optimalisasi pendapatan.

2. Sosialisasi terhadap konsep balance scorecard harus dilakukan sebelum menerapkan konsep ini dalam pengukuran kinerja.

\section{DAFTAR PUSTAKA}

[1] Kaplan, R.S. \& Norton, D.P., 1996. Balanced Scorecard: Translating Strategy Into Action, Harvard Business School Press.

[2] Mulyadi, 2001. Balanced Scorecard: Alat Kontemporer untuk Pelipatganda Kinerja Keuangan Perusahaan. Jakarta: PT Salemba Empat. 
[3] Saaty, T.L., 1990. The Analytic Hierarchy Process: Planning, Priority, Setting, Resource Allocation. Pittsburgh: University of Pittsburgh Press.

[4] Turban, E., 2005. Decision Support Systems and Intelligent Systems Edisi Bahasa Indonesia Jilid 1. Yogyakarta: Andi.

[5] Sholihah, M., 2012. Perancangan Sistem Pengukuran Kinerja ITS International Office dengan Menggunakan Balanced Scorecard, JURNAL TEKNIK POMITS. 1(1): 1-5.

[6] Vanny, I., 2003. Aplikasi Analytic Network Process (ANP) pada Perancangan Sistem Pengukuran Kinerja Pada PT. X, JURNAL TEKNIK INDUSTRI. 5(1): 50-62.

[7] Irawan, M., 2015. Pengukuran Kinerja Perusahaan dengan Metode Balanced Scorecard, E-JURNAL UPM. 5(2). 